\title{
EMPREGO DAS ONDAS RAYLEIGH VISANDO À CARACTERIZAÇÃO GEOTÉCNICA DE SOLOS SUPERFICIAIS DE ENCOSTA NUMA ÁREA TESTE EM UBATUBA/SP
}

\author{
Sergio Bezerra Lima Júnior \\ Orientador: Dr. Renato Luiz Prado (IAG-USP) \\ 96 p. - Dissertação (Mestrado) - Defesa 26.04.2007
}

RESUMO. Este trabalho apresenta e discute o emprego do método MASW (multichannel analysis of surface waves) a partir de resultados obtidos em um levantamento em área de erosão e escorregamento no município de Ubatuba, estado de São Paulo. 0 método MASW busca obter um perfil 1D ou seção 2D do campo de velocidades da onda S (Vs) a partir da inversão da curva de dispersão obtida do registro das ondas superficiais. Apresenta grande potencial de emprego para a caracterização geológico-geotécnica de maciços geológicos em projetos de engenharia e meio ambiente. Aqui são apresentados e discutidos aspectos relacionados à aquisição, processamento e inversão dos dados. Sendo a área dos estudos constituída basicamente de solos não saturados e sujeita a regimes pluviométricos bem distintos entre os períodos de verão e inverno, buscou-se analisar 0 quanto o método é sensível a possíveis mudanças sazonais dos valores de velocidades das ondas $S$ em função da variação do grau de saturação que traz mudanças no regime de tensões capilares do solo. A análise comparativa entre os resultados das inversões nos distintos períodos mostrou que os valores de velocidade da onda $S$ do período mais seco (ensaios realizados no mês de agosto) foram superiores aos do período das chuvas (ensaios realizados em abril), mas semelhantes no que diz respeito ao modelo 1D final dos estratos presentes. 0 modelo final 1D de velocidades com a profundidade apresentou coerência com os resultados de outras investigações geofísicas (sísmica de refração e GPR) e geotécnicas (análise granulométrica e mapeamento) feitas no local, atestando a eficiência do método. Para os sedimentos mais superficiais foram mapeadas três interfaces: a primeira a um metro de profundidade, a segunda a quatro metros e a terceira a oito metros. Embora sejam necessárias outras investigações geológico-geotécnicas de detalhe para uma boa caracterização das propriedades geotécnicas do maciço, como a obtenção de curvas de tensão de sucção, ensaios triaxiais, etc., o resultado apresentado mostra ser possível a idéia de se buscar correlações empíricas sítios-dependentes entre Vs (ou do módulo de cisalhamento dinâmico), obtido com o método MASW, e parâmetros de resistência do maciço que permitam o monitoramento contínuo de áreas de instabilidade.

ABSTRACT. This work presents and discusses the MASW method (Multichannel analysis of surface waves) through a case study in an unstable hillside area in the city of Ubatuba, State of São Paulo. The MASW method has been developed for determining the 1D profile or 2D section of the shallow shear wave velocity field that can be derived from inverting the dispersive phase velocity of the surface waves. It has great importance for geotechnical engineering and environmental projects. The MASW involves three steps that are discussed here: the acquisition of the surface waves, the processing (to obtain the dispersion curve) and the backcalculation (inversion) of the Vs profile. As the study area has basically unsaturated soil and also very distinct rain index during the year, another aim of this research was to verify if this technique could be used to assess seasonal effects on $S$ wave velocities, and consequently, on soil parameters. It is known that the moisture content changes the capillarity stresses and consequently the soil strength. Two series of tests were conducted in April (end of the wet season) and August (dry season) of 2006. The results show that the S wave velocity in August is higher than the one in April, but the $1 \mathrm{D}$ profile are similar in both cases and also agree with the results from GPR and seismic refraction tests done in the same area. The shallow Vs 1D profile show three main interfaces: at one, four and eight meters of depth. Although other in situ and laboratory geotechnical tests (compression, moisture content, suction pressure, etc.) are necessary, the results suggest that it is possible to use empirical correlations between the Vs profile, from MASW method, and other strength soil parameter in order to monitor areas susceptible to slope instability. 